УДК 94(571.1)

ББК 63.3(2)5

DOI 10.17150/2308-2588.2017.18(2).359-383

А. К. Кириллов

Новосибирский государственный университет,

Институт истории СО РАН, г. Новосибирск, Российская Федерация

М. А. Гордеев

Институт истории СО РАН, г. Новосибирск, Российская Федерация

А. Г. Караваева

Государственный архиһ Томской области, г. Томск, Российская Федерация

\title{
СЕЛЬСКОХОЗЯЙСТВЕННЫЕ РЕСУРСЫ ОБЩЕГО ПОЛЬЗОВАНИЯ В ЗАПАДНОСИБИРСКОЙ ДЕРЕВНЕ: МеханизМ возНИкНовения старожильческо-переселенческих конфрликтОв В 1870-1890-е годы. Антоньевский случайю
}

\begin{abstract}
Аннотация. Столкновения между новосёлами и старожилами, возникавшие по ходу великого сибирского переселения второй половины XIX - начала XX в., представлены как один из случаев конфликтов вокруг ресурсов общего пользования. Показано, что конфликт на землях станицы Антоньевской, разгоревшийся в конце 1880-х гг., коренится в начале 1870-х гг., когда начался быстрый рост переселения из российских губерний на казачьи земли. В Антоньевском случае выделяются не две, а три группы интересов: казаки-старожилы, «приёмные переселенцы» (официально допущенные казаками) и «новые переселенцы» (появление которых и вывело систему из равновесия).
\end{abstract}

* Окончание, начало см.: Историко-экономические исследования. 2017. Т. 18, № 1. С. 193-218. 
Ключевые слова. Крестьянское переселение в Сибирь, Сибирское линейное казачье войско, приёмный приговор, «разночинцы», посаженная плата.

\author{
A. K. Kirillov \\ Novosibirsk State University, \\ Institute of History of the SB RAS, \\ Novosibirsk, Russian Federation \\ M. A. Gordeeva \\ Institute of History of the SB RAS, \\ Novosibirsk, Russian Federation
}

A. G. Karavayeva

State archive of the Tomsk region, Tomsk, Russian Federation

\title{
AGRICULTURAL GOMMON-POOL RESOUREES

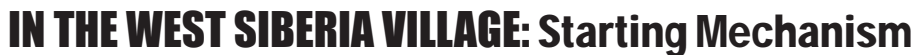 of Conflicts between Peasant Migrants and Old Dwellers in the 1870s-1890s.

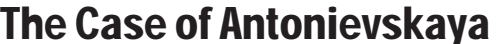

\begin{abstract}
Collisions between newcomers and old inhabitants that happened during the Great Siberian migration (1850s - 1910s) are presented as a sort of conflicts concerning common-pool resources. It is shown that the conflict at the Antonievskaya cossack village land allot that flared up at the late 1880s years was rooted in the early 1870s when a rapid growth of peasant migration to the cossack lands began. As much as three groups of interest acted at Antonievskaya: cossack old dwellers, «adopted migrants» (that acquired official permission of the cossacks) and «new migrants». It was the emergence of latter group that upset the balance.

Keywords. Peasant migration to Siberia, Siberian Linear cossack army, newcomers versus old dwellers, admission act (priyomnyi prigovor), commoners (raznochitsy), square rent (possazhennaya plata).
\end{abstract}




\section{Второй фронт}

Особенность Антоньевского противостояния наличие двух разных групп переселенцев. Уже упоминалось, что Н. Г. Казнаков, дав поблажку переселенцам, всё-таки постановил не имеющих приёмные приговоры выселить на речку Грязнуху. Логично предположить, что речь идёт о ранних переселенцах - успевших получить приговоры, и поздних переселенцах - не успевших. Разобранные выше приговоры показывают, что жизнь была более сложной: и в начале 1880-х годов выдача приёмных приговоров продолжалась. Вероятно, те, кто готов был заплатить за приговоры, всё-таки могли это сделать. Как бы то ни было, переселенцы разделились, выражаясь их языком, на «приёмных» и «неприёмных».

Самая ранняя известная нам жалоба (от 19 июня 1889 г.) исходит именно от «неприёмных» (интересы которых представляют крестьяне Куранов и Жуков).

Жалуясь на посаженную плату за усадьбы, они сообщали: «Во всех поселках станицы с переселенцев посаженная плата не взыскивается, а только с нас 65-ти домохозяев, а все[х] переселенцев в районе станицы находится около 900 домов каковые получая все удовольствие: как пахотныя земли так и сенокосныя места от казачьих обществ а мы пользуемся на вновь произведенной местности Алтайским Горным правлением на Речке Грязнухе, где ожидается новое заселение как нам так и доверителям нашим от Кабинета Его Императорского Величества на что потребуется немало издержек» ${ }^{1}$.

Полезно сопоставить эти цифры с данными сентябрьской ведомости Мархинина: оценка общего числа переселенцев («около 900 домов») близка к данным атамана (731 семья). При этом в посёлке Терском зна-

${ }^{1}$ Государственный архив Томской области (ГАТО). Ф. Ф-3. Оп. 44. Д. 148. л. 36-36 об. 
чится 143 семейства «приёмных» и 103 «неприёмных» переселенцев. Почему жалоба идёт не от 103, а от 65 семейств - вопрос отдельный. Можно предположить, что «неприёмные» переселенцы не были едины; окончательных данных на эту тему нет.

В любом случае ясно, что решение Казнакова в отношении «неприёмных» переселенцев сработало лишь отчасти: пашню в новом месте они уже используют, но «новое заселение» ещё только ожидается. Вероятно, задержка эта была связана с необходимостью межевых работ со стороны Кабинета: в том же ходатайстве переселенцы сообщали, что есть «распоряжение Помощника по земельной части Алтайского Горного Округа, каковое нам объявлено, где сказано проживать нам свободно до вырешения дел в Кабинете Его Императорского Величества и сообщено что будет размежевание земель в настоящем году» ${ }^{2}$.

Крестьянское присутствие, в которое попала эта бумага, явно было недовольно: чиновники не только указали просителям на нарушение протокола (к прошению требовалось представить доверенность от тех, чьи интересы защищаются), но и довольно язвительно обозвали авторов документа «именующими себя поверенными» ${ }^{3}$.

Канцелярский обмен занял немалое время: 17 сентября ответ губернского правления был послан переселенцам, 8 октября они составили общественный приговор с поручением Куранову и Жукову отстаивать их интересы ${ }^{4}$. Этот краткий документ интересен самоназванием жалобщиков: «мы, нижеподписавшиеся Тамбовские переселенцы, проживающие временно в поселке Терском Станицы Антоньевской Бийскаго Округа». Таким образом, переселенцы были как минимум из одной губернии. Если даже их не объединяло

${ }^{2}$ ГАТО. Ф. Ф-З. Оп. 44. Д. 148. Л. 36 об.

3 Там же. Л. 35.

${ }^{4}$ Там же. Л. 41. 
происхождение из одного уезда или волости, всё-таки можно полагать, что в посёлок Терский они прибыли как единая группа, сплачиваемая земляческим единством.

Новое ходатайство тех же доверенных ${ }^{5}$ составлено 7 декабря 1889 г. (через два месяца после оформления доверенности!). Это ходатайство даёт новые подробности. Именно здесь и сообщается, что точкой обострения стал 1885 год. Здесь же чётко формулируется наличие не просто различия, но противоречия интересов между приёмными и неприёмными переселенцами.

Своих противников Куранов и Жуков обозначают так: «казаки поселка Терского и проживающие крестьяне прежде пришедшие нас сего же поселка». Вот что пишут жалобщики: выпуск переселенческого скота был «весьма стеснен пользованием подножным кормом в 1885 году, в которое время мы были принуждены казаками и упомянутыми выше крестьянами скот отправить на вновь определенны[й] участок где мы все почти потеряли все свое скотоводство и по настоящее время обзавестись не можем, а Кабинет Его Императорского Величества новое заселение нам еще не разрешил на выше сказанной земле, а без приютных построек и без удобных водопоев скотоводство принуждено усиленно падать» ${ }^{6}$. По-видимому, именно в 1885 г. переселенцев выгнали на р. Грязнуху.

И этим дело не ограничилось. Читаем далее: «На основании предписания Хозяйственного Управления Казачьего Сибирского войска от 21 октября 1885 г. мы должны свой скот продовольствовать бесплатно при поселке Терском, так как мы согласно сказанного предписания за № 7735 должны за свой скот нести все сопряженные повинности что нами исполняется, но казаки и вышесказанные крестьяне, не смотря ни на какие законы, имеют цель скот наш выгнать». В доказа-

${ }^{5}$ ГАТО. Ф. Ф-3. Оп. 44. Д. 148. Л. 39-40.

6 Там же. Л. 39 об. 
тельство платежей, достигавших, по словам переселенцев, 100 р. в год (со всех семейств), они прикладывали три квитанции 1887 г. на 86 рублей.

Итак, в 1885 г. спор между казаками и переселенцами уже выносился на рассмотрение высшего казачьего начальства. Несмотря на решение в пользу переселенцев, терские казаки и «приёмные» переселенцы продолжили борьбу за свои ущемлённые права. Как видно, в посёлке Терском пастбища уже в 1885 г. были остро дефицитны.

Из жалобы неприёмных переселенцев складывается впечатление, что приёмные переселенцы действуют заодно с казаками. Тем не менее, в жалобе «приёмных» переселенческому чиновнику (1890 г.) читаем: «Ваше Высокоблагородие отношением от 30-го декабря 1887 г. за № 1274, на имя Антоньевского Станичного Правления изволили объявить нам, что Вы предложили Станичному Правлению объявить казакам Николаевского Поселка, что дело о переселенцах, живущих на казачьих землях находится уже на разрешении Кабинета Его Императорского Величества. Получив такое распоряжение, действительно бывший Станичный Атаман Мокин освобождал нас от излишних сборов, но в настоящее время поступивший на место его Атаман Мархинин, даже за какия-то квадратные и за землепользование просит с нас деньги» ${ }^{7}$

Как видно, противостояние происходило на двух уровнях. Все вместе переселенцы были недовольны посаженной платой, а казачье начальство - их отказом эти деньги уплачивать. Вялотекущее это противостояние не задевало жизненных интересов ни одной из сторон и могло продолжаться долго. Более острую форму приобрела борьба за выгоны, ставшие дефицитными прежде всего в том посёлке, куда направлялось более всего переселенцев. Здесь водораздел проходил не по

${ }^{7}$ ГАТО. Ф. Ф-3. Оп. 44. Д. 148. Л. 47. 
сословной границе; он разделил крестьян раньше и позже пришедших. Жизненная необходимость выпасов для скота и жизненная необходимость скота для крестьянина делали это противостояние более накалённым.

Именно из-за появления «поздних переселенцев» хрупкое равновесие конца 70-х - первой половины 80-х годов было нарушено в 1885 г. Скот «неприёмных переселенцев» был в значительной части изгнан с выгодных пастбищ и погиб, оставшейся части грозила та же участь. В 1889 г. взаимное недовольство вновь стало перерастать в конфликт; перед лицом неминуемого поражения крестьяне вновь подключили к нему начальство.

\section{॥Игра в одни ворота॥: позиция местных властей в 1889 году}

Жалобы и старых, и новых переселенцев в 1889 и начале 1890 г. не вполне обычны. Они были адресованы не ближайшему начальству (чиновник по крестьянским делам), не губернатору, а томскому переселенческому чиновнику. В 1889 г. должность «чиновника, командированного для заведования переселенческим делом в г. Томске» занимал Аркадий Аполлонович Чарушин; в тот год ему исполнилось 33.

Г. И. Успенский, наблюдавший отчаянные картины переселенческих страданий в 1888 г., неоднократно упоминает А. А. Чарушина как неравнодушного чиновника, старавшегося, чтобы помощь переселенцам выходила за рамки скудных инструкций [4]. Двое братьев Аркадия заняли, каждый - по-своему, видное положение. Старший, Николай - известный революционер (получивший 9 лет каторги по знаменитому «процессу 193-х»), Иван - губернский архитектор (сын его, Е. И. Чарушин, станет известным писателем).

Двоюродный брат Чарушиных (по возрасту, правда, годившийся им в сыновья) В. И. Юферев (сам в начале $X X$ в. работавший некоторое время в Пересе2017. T. 18, № 2. C. 359-383 
ленческом управлении, как раз по протекции А. А. Чарушина $)^{8}$ характеризовал Аркадия - очевидно, по контрасту со старшим братом - как «до мозга костей чиновника» и «ретрограда». Доказательствам этого выступали чтение суворинского «Нового времени», «щеголяние» костюмами и покупка мест в партере театра. «С другой стороны, - замечает Юферев, - с Арк. Аполл. поговорить было интересно. По натуре он был живой человек, с готовностью откликался на задаваемые ему вопросы, старался разрешать их по мере имеющегося у него объема знаний и сведений» [1]. В 1910-е гг., уже работая на европейском севере, А. А. Чарушин выпустил серию брошюр с описаниями народного быта?.

А. Ж. Мырзахметова со ссылкой на фонд канцелярии Степного генерал-губернатора цитирует доклад А. А. Чарушина в Земский отдел МВД. Заступник переселенцев сетовал на отсутствие единства в деле «учреждений и лиц, ведающих переселенческим делом на местах» и предлагал создание самостоятельного Переселенческого управления для помощи переселенцам в пути и устройства их на новых местах (включая выдачу разрешений на переселение, выдачу денежных ссуд, обмежевание земель, образование отдельных сельских обществ) [2]. От Глеба Успенского мы знаем, что Чарушин задумывался и о специальном переселенческом

${ }^{8}$ Юферев Вячеслав. Воспоминания. С. 332. [Неизданная рукопись 1959 г. Сканированная копия. Архив сектора истории второй половины XVI - начала XX века Института истории СО $\mathrm{PAH}]$.

${ }^{9}$ Крестьянские переселения в бытовом их освещении (Архангельск, 1911. 17 с.), Крестьянские сходы в бытовом их освещении (Архангельск, 1911. 16 с.), Взгляд народа на преступление (Архангельск, 1912. 8 с.), Волостные суды в бытовом их освещении (Архангельск, 1912. 13 с.), Народный суд (Архангельск, 1913. 15 с.), Отбывание народом повинностей: денежное обложение (Архангельск, 1913. 13 с.), Отбывание народом повинностей: натуральные повинности (Архангельск, 1914. 14 с.), Трезвая Русь (Архангельск, 1914. 7 с.). 
банке. Переселенческий банк так и останется мечтой, Переселенческое управление будет создано в 1896 г. но уже после того, как А. А. Чарушин покинет Сибирь. Один из мартовских 1890 года документов мимоходом сообщает нам о появлении в Томске нового переселенческого чиновника. Новая должность: «Чиновник особых поручений по переселенческим делам при Земском отделе Министерства внутренних дел». Новое лицо: не вполне разборчивая подпись напоминает фамилию «Ишотов»; во всяком случае, ясно, что это уже не Чарушин. Должности были преемственными: как видно из письма губернатору, «и.д. чиновника особых поручений» воспринимал Чарушина в качестве своего предшественника ${ }^{10}$.

Впрочем, и сам Чарушин, при всём его энтузиазме, был ограничен в средствах. Получаемые от крестьян жалобыонпрепровождалгубернатору «на распоряжение». Вершителями судеб переселенцев в начале 1890-х гг. оставались представители традиционной губернской «вертикали власти». Именно от их позиции во многом зависел выход положения из равновесия в 1889 г.

Уже цитировалось обращение «старых переселенцев» ${ }^{11}$, где смена позиции казаков связана со сменой атамана (Мархинин вместо Мокина). Но дело не в Мархинине. Полугодом ранее новые переселенцы сообщали, что «Атаман же Станицы Морхинин в 1889 году, плату за выпуск скота брать согласно предписания за № 7735 не приказал, на что общество казаков и прежде пришедшие крестьяне волнуются. Почему вынужденными находимся покорнейше просить Ваше Высокопревосходительство от насильственных притеснений нас освободить или сделать со своей стороны законное постановление» ${ }^{12}$. Как видно, источник антипереселенческой силы - «общество», недовольное уме-

${ }^{10}$ ГАТО. Ф. Ф-3. Оп. 44. Д. 148. Л. 46.

11 Там же. Л. 47.

12 Там же. Л. 40. 
ренностью атамана. Надо полагать, именно давление «общества» казаков и обусловило появление в 1889 г. нескольких переселенческих жалоб, самая ранняя из которых (не дошедшая до нас) датирована 25 февраля - заведомо до начала полевого сезона!

Тем не менее, атаман Мархинин был деятельным участником процесса. До нас дошла составленная им ведомость о количестве переселенцев в станице Антоньевской и о суммах, полученных с 1871 по 1889 г. Ведомость эта «составлена 12 октября 1890 г. со списков, представленных г. Бийскому окружному исправнику 20 сентября 1889 г. за № 1468». Указание делопроизводственного номера не оставляет сомнений в том, что речь идёт о письменном обмене. Значит, в то время, когда известные нам летне-осенние жалобы переселенцев были ещё только на пути к рассмотрению, казаки-старожилы уже вели борьбу против переселенцев - как раз через того полицейского чиновника, который через полгода окажется ревностным исполнителем антипереселенческого решения губернатора.

Действия станичного атамана Мархинина опирались на распоряжения более высокого начальства. Вот о чём сообщает один из документов, исходящих от губернского правления: «Согласно последовавшему в 1889 г. распоряжению войскового наказного атамана Сибирского казачьего войска, переселенцы поселка Терского и других, за исключением избавленных на время по распоряжению бывшего генерал-губернатора Западной Сибири в 1875 году от взноса в станичный доход поземельных денег, были обязаны уплачивать поземельные деньги, а в отношении пользования покосами и пашнями, а также пользования пастбищами с промышленною целью - входить каждый раз в соглашение с казачьими обществами» ${ }^{13}$.

${ }_{13}^{13}$ ГАТО. Ф. Ф-3. Оп. 44. Д. 148. Л. 49 (черновик ответа губернатора в Канцелярию прошений, на высочайшее имя приносимых). 
Так впервые появляется фигура «войскового наказного атамана». Должность эта была «привязана» к должности Степного генерал-губернатора, и как раз в 1889 г. здесь произошла смена действующих лищ: Г. А. Колпаковского сменил М. А. Таубе. Вероятно, казакам удалось получить поддержку у вновь пришедшего генерала-кавалериста.

Впрочем, это решение не было разрывом с предыдущим: ведь постановление касалось только новых переселенцев, не подлежащих льготе 1875 года. По-настоящему крутая перемена произошла в деле в январе 1890 г.

Отпечатанное типографским образом «объявление» бийского окружного исправника Поршенникова датировано 22 марта 1890 г. Исправник сообщал: томский губернатор «предписанием от 30 минувшего Января за № 68, изволил обязать меня взыскать со всех разночинцев установленную законом плату в станичный доход - начиная с 1875 года» ${ }^{14}$. В качестве законодательной основы указывались высочайше утверждённые мнения Госсовета от 29 апреля 1868 г. и от 13 мая 1870 г. согласно которым «лица не войскового сословия (т. е. разночинцы), проживая в казачьих поселках собственными домами - обязаны ежегодно платить в станичные суммы установленную плату: за усадебные места», а за пашни и покос - «по условию с казаками». Между тем, с 1875 г. переселенцы казакам не платили («пользуясь, при том, землею с промышленной целью» - вероятно, речь о скотоводстве) и потому должны заплатить за все минувшие годы.

«Объявление» Поршенникова оформлено действительно как объявление - с крупным, броским заголовком, хоть на забор вывешивай. А. В. Старцев и В. М. Антропов, ссылаясь на дневниковые записи Е. В. Клевакина, помощника Поршенникова, пишут о

${ }^{14}$ ГАТО. Ф. Ф-3. Оп. 44. Д. 148. Л. 24. 
«многочисленных фактах злоупотреблений» последнего в виде взяток и поборов с кабаков и домов терпимости. Своего начальника Клевакин аттестовал язвительно: «Все, что сделано хорошо, он приписывает себе и говорит: “Я сделал", “Я так приказал”. А если что сделано по его приказанию, но выйдет плохо, то он отказывается от своего приказания и говорит: “Я приказал сделать иначе, но меня не поняли” » [3]. Похоже, что в губернаторском постановлении опытный исправник увидел источник дохода не хуже кабака или публичного дома.

Итак, жалоба губернатору не только не принесла пользы переселенцам, но ухудшила их положение. Очевидно, что даже необременительный платёж превращается в разорительное наказание, если взыскивается сразу за 15 лет. Такой резкий антикрестьянский крен настолько резко контрастирует со всей предыдущей политикой властей, что требует какого-то объяснения. Может быть, причина поворота связана с личностью губернатора? Попытка ответить на этот вопрос наталкивает нас на удивительный факт: 30 января 1890 г. губернатора в Томске не было. Губернатор А. П. Булюбаш как раз незадолго до этого умер, Г. А. Тобизен ещё оставался Лифляндским генерал-губернатором. На время «пересменки губернаторов» должность начальника губернии временно замещал В. Г. Котюхов, с сентября 1889 по октябрь 1890 г. руководивший Томским губернским правлением [5, с. 133]. Важная подробность: до Томска В. Г. Котюхов служил вице-губернатором в Семипалатинской области. По-видимому, опыт жизни в этом краю, где узкая полоска земель Сибирского линейного казачьего войска служила оплотом русской культуры перед лицом степных кочевников, и предопределил стремление временного начальника губернии грудью стать на защиту казачьих интересов.

Вот теперь и спор о посаженной плате перестал быть второстепенным. Именно теперь, в марте 1890 г., 
выбранным ещё три года назад доверенным от переселенцев Яковенко и Андриенко приходится сочинять жалобу, которая от переселенческого чиновника будет переправлена губернатору. Казаки, как пишут доверенные, приступили к реквизициям имущества за неплатёж посаженных денег; атаман Мархинин, «приезжая в поселок Николаевский, на полном сходе неоднократно говорил: “Я вас, разночинцев, поем, а казакам буду родной отец"» ${ }^{15}$. Доверенные просили защиты от притеснений казаков.

Препровождая это письмо к губернатору, переселенческий чиновник уточнил, что делает это «в дополнение к представлениям моим от 25 февраля и 13 июля 1889 г.» ${ }^{16}$. При этом указываются и номера, не оставляющие сомнений в том, что представление 13 июля 1889 г. - это то самое, которым препровождалось июньское прошение Куранова и Жукова. Отношение от 25 февраля до нас не дошло, но в отношении от 13 июля оно упоминалось с той же присказкой: жалоба Куранова и Жукова пересылалась «в дополнение» к этому документу. Значит, и прошение «новых переселенцев», и прошение «пришедших прежде» для чиновника являются звеньями одной цепи, тянущейся из более раннего времени.

Так в 1890 г. за счёт неожиданного вмешательства недостаточно опытного губернатора конфликт между «старожилами» (имея в виду казаков и «старых переселенцев») и новыми переселенцами в посёлке Терском перерос в конфликт между казаками и переселенцами во всей станице Антоньевской.

\section{॥Ходатай по делами: временный успех переселенцев}

С марта 1890 г. до августа 1891-го у нас нет определённых сведений о ходе конфликта. Известно лишь,

${ }^{15}$ ГАТО. Ф. Ф-3. Оп. 44. Д. 148. Л. 47 об.

16 Там же. Л. 46. 
что в октябре и в декабре 1890 г. атаман Мархинин подавал наверх ведомости сначала о сборах, требуемых казаками с переселенцев, а затем - о зажиточности переселенцев. По-видимому, новый начальник губернии Г. А. Тобизен (прибывший в Томск 30 июня 1890 г.) всё же приостановил «кавалерийскую атаку» на крестьян и задался вопросом о степени обременительности для переселенцев назначенных им платежей. Но в целом, видимо, обстановка развивалась не в пользу переселенцев: во всяком случае, в следующем году им пришлось браться за дело всерьёз, искать сведущего помощника.

На исходе августа 1891 г. из Терского посёлка в Томск было отправлено прошение А. 3. Платонова на имя губернатора ${ }^{17}$. Сам из тех, кто прибыл в Сибирь «много лет тому назад», он был выбран товарищами в качестве доверенного по защите общих интересов.

Особенность этого документа - стиль, которым он написан: в отличие от полубессвязных косноязычных фраз предшественников, со стороны А. 3. Платонова мы видим первоклассное публицистическое произведение, выдающее знакомство автора и с высокой литературой, и с правилами риторики, и с действующим законодательством. «Каждый бездомный бродяга-переселенец, потерявший родину и не нашедший здесь приюта, благодаря Высочайше утвержденному 13 июля м.г. ${ }^{18}$ мнению Государственного Совета, может причислиться без труда к любому месту водворения и найти условия, благоприятные для существования; мы же, порвавшие связь с нашей родиной, ведем полную всяческих мук, непрестанную борьбу за право питать себя честным заработком» ${ }^{19}$. Трудно поверить, что шесть страниц такого текста принадлежат крестьянину, от зари до зари занятому сельскими работами.

\footnotetext{
17 ГАТО. Ф. Ф-3. Оп. 44. Д. 148. Л. 28-31.

18 В данном случае «минувший» год - это, конечно, не 1890й, а 1889-й.

${ }^{19}$ ГАТО. Ф. Ф-3. Оп. 44. Д. 148. Л. 30-30 об.
} 
Да и красивый слегка витиеватый почерк явно не принадлежит ни самому ходатаю переселенцев (неграмотному), ни расписавшемуся по его просьбе камышловскому мещанину Л. М. Моисееву, ни местному писарю (руку которого мы видим в сопутствующих документах). По-видимому, переселенцы приобрели неплохо образованного помощника, который помог им «показать товар лицом». Незаметная армия частнопрактикующих «ходатаев по делам» не оставила после себя архивных следов, и только благодаря литераторам да художникам-передвижникам мы можем судить о многочисленности этой армии в пореформенной России.

Автор прошения Платонова рисует самые мрачные перспективы развития дела («предоставление нас произволу и разнузданности казаков может породить лишь бесплодные кровопролития»), но просьбу формулирует расплывчато: «умоляю Ваше Превосходительство подвергнуть тщательному расследованию наше печальное, созданное годами недоразумений, положение и изыскать какие-либо средства для его облегчения». Впрочем, по части конкретных требований этот документ дополняется другим, составленным 6 августа. Представитель переселенцев не имел права действовать без официальной доверенности; А. З. Платонову этот документ был оформлен в виде общественного приговора «разночинцев, проживающих в поселке Терском» ${ }^{20}$. Среди подписавших - «крестьяне, мещане, нижние воинские чины». Использование почти правильной формулы стандартного общественного приговора («быв сего числа на общественном сходе в присутствие полицейского сотского Королёва, в числе 2/3 общественных голосов») указывает на стремление представить себя именно как единое общество, а не отдельных переселенцев. Просьба общества формулируется кратко, но масштабно: «Ходатайствовать от

${ }^{20}$ ГАТО. Ф. Ф-3. Оп. 44. Д. 148. Л. 32-32 об. 
высшего начальства разрешение о сложении с нас прописанной выше посаженной платы, и причислении нас с уплатой крестьянских податей». Непонятно, содержится ли в требовании крестьянских податей отказ от подесятинной платы, или только от посаженной, но ясно, что крестьяне жалобщики претендовали получить наконец статус полноценных крестьян, оставаясь на прежнем жительстве.

Прошение Платонова прибыло по назначению почти месяц спустя. Взяв рутинную паузу ещё в месяц, губернское управление начало двигать дело обычным порядком и 16 октября 1891 г. запросило разъяснений у подлежащего чиновника по крестьянским делам ${ }^{21}$. Вероятно, правление надеялось, что если не спешить с ответом, то проблема сама «рассосётся», как то случилось с жалобами Куранова и Жукова, а также Яковенко и Андриенко. Вскоре губернатору пришлось убедиться, что проблема не рассосалась. 5 ноября в губернаторскую канцелярию поступило отношение из Канцелярии прошений, на высочайшее имя приносимых, с запросом сведений по прошению крестьянина пос. Терского А. Платонова 22 .

Так выяснилось, что переселенцам известны инстанции и повыше, чем нерасторопный губернатор. Прошение на царское имя, согласно требованию Канцелярии прошений, было возвращено в столицу оно не дошло до нас ни в подлиннике, ни в копии. Но известен ответ на обращение Платонова к царю (уже после пересылки его в Томскую губернию) одного из чиновников. Вот что он писал губернатору: «Что же касается до ходатайства переселенцев о причислении их к ближайшим крестьянским волостям, то они желают быть причисленными к таковым при том лишь условии, чтобы и сам поселок Терский обращен был в крестьянское селение, подобно тому, как это было сде-

${ }^{21}$ ГАТО. Ф. Ф-3. Оп. 44. Д. 148. Л. 31 об.

${ }^{22}$ Там же. Л. 1. 
лано с поселками расположенными по Кузнецко-Бийской линии, земли которых, за упразднением этих поселков, поступили в ведение Кабинета Его Величества и заселены крестьянами» ${ }^{23}$. Если всё это взято не из личного общения с крестьянами, а из ходатайства, то можно сказать, что автор прошений проявил творческий подход: обращения в разные инстанции составлены по-разному.

Кроме того, известно, что отношение Канцелярии было отправлено 10 октября - за неделю до того, как губернатор отреагировал на обращение в собственный адрес. Логично думать, что два прошения (губернатору и царю) были отправлены одновременно. Даже если это не вполне верно, всё-таки ясно, что Платонов не собирался робко и бесконечно ждать, пока власти снизойдут до интересов его заявителей.

Губернатору пришлось ещё раз потеребить бийское начальство: всеподданнейшая жалоба вновь была переслана чиновнику по крестьянским делам 1-го бийского участка ${ }^{24}$, причём с требованием уже не только «сведений» (как в прошлый раз), но также и «заключения».

Между тем, настойчивость Платонова ещё не была исчерпана. Больше трёх месяцев не имея ответа ни от губернатора, ни от царя, он 5 декабря отправил новое прошение ${ }^{25}$. Продолжая прежнюю линию, он, однако, старался не повторяться и подчеркнул ту сторону дела, которая упоминалась прежде лишь вскользь: наличие казачьих «приговоров», оформляющих допуск переселенцев. Не ограничиваясь риторикой, А. З. Платонов приложил и копии пяти приёмных приговоров

${ }^{23}$ ГАТО. Ф. Ф-З. Оп. 44. Д. 148. Л. 19-19 об.

${ }^{24}$ В черновом отпуске написано - 2-го участка. Это явная ошибка. И предыдущее отношение отправлялось в 1-й участок, и ответ с возвратом прошения на высочайшее имя будет получен именно из 1-го бийского участка.

${ }^{25}$ ГАТО. Ф. Ф-3. Оп. 44. Д. 148. Л. 8-9. 
от 1873 до 1881 года. Случайно или нет взяты Платоновым именно эти пять приговоров, очевидно, что все рассматриваются обеими сторонами (и крестьянами, и казаками) как преемственные, однородные. В совокупности эти документы (подробно разобранным выше) не оставляют сомнений, что казаки изначально собирались применять те законы, которые и дают им право требовать того, что они требуют на самом деле. Переселенцы, по-видимому, этих законов не знали, и смысл их представляли неточно. Обязательства переселенцев Платонов трактует как обещание платить «обыкновенный, принятый в среде казаков налог» - и это противоречит тексту даже 1-го приговора, где говорится про «установленную законом плату», и тем более противоречит более поздним приговорам, где указываются конкретные законы, где крестьяне прямо противопоставлены казакам. Тем не менее, Платонову удалось обернуть юридический козырь против той стороны, которая использовала его до сих пор.

Получив 18 декабря 1891 г. пачку документов от Платонова, губернатор понял, что недооценил переселенцев. Имея третье подряд обращение по одному и тому же поводу, и по-прежнему не имея ответа от крестьянского чиновника, губернатор решил впредь до разбора дела вступиться за переселенцев, действуя через полицию. На декабрьском обращении Платонова он наложил резолюцию: «Затребовать объяснение от исправника и предписать ему оградить переселенцев от притеснений» ${ }^{26}$. Отношение с этими поручениями ушло к исправнику уже после рождественских праздников, 15 января 1892 г.

\section{Последний компромисс и последняя загадка}

Видя, что маятник качнулся в обратную сторону, станичный атаман вновь ринулся в бой. 24-м февраля

${ }^{26}$ ГАТО. Ф. Ф-3. Оп. 44. Д. 148. Л. 8. 
1892 г. датирован документ с необычным названием: «Надпись на предписании Г. Бийского Окружного Исправника 11 февраля 1892 г. № 449, по просьбе крестьянина Артамона Платонова, поданной Г. Томскому губернатору 5 декабря 1891 года» ${ }^{27}$. По существу это прошение, протест казаков против губернаторского предписания от 15 января (которое, очевидно, и дублировал бийский исправник в не дошедшем до нас предписании от 11 февраля). Вновь повторяя доводы о законах, казаки между делом сообщают, что существенно скостили ставки: с переселенцев, «в уважение бедности некоторых из них», Антоньевский станичный сход постановил взыскивать долг не за 17 лет, а 5 последних (начиная с 1887 г.).

Попутно атаман Мархинин добавлял немного чёрной краски к портрету крестьян, которые «по привычке, положительно не исполняют» требование платить за пашню и покос, притом нарушают и другой пункт соглашения, «выезжая в поле на лучшую землю без всякого дозволения кого бы то не было, а чрез это, само собою разумеется, происходят большие ссоры, а в 1888-м году в Терском даже была и драка из-за покоса» ${ }^{28}$.

По весне 1892 г. начали поступать и ответы от представителей власти. Первым прислал рапорт ${ }^{29}$ бийский исправник ${ }^{30}$. В Томске этот документ был получен 26 марта. Его основная часть близко к тексту повторяет «надпись» атамана Мархинина, включая и художественные обороты - о том, что станичное правление день и ночь бесплатно работает на переселенцев (поскольку они не платят местных сборов) и том, что переселенцы устроились не хуже бывших помещиков (и

27 ГАТО. Ф. Ф-3. Оп. 44. Д. 148. Л. 25-26 об.

${ }^{28}$ Там же. Л. 26 об.

29 Там же. Л. 5-7 об.

30 Подписан «за исправника» его помощником; судя по подписи, можно допустить, что это цитированный выше Клевакин. Поршенников упоминается в тексте уже как бывший исправник. 2017. T. 18, № 2. С. 359-383 
государственных налогов тоже не платят). В итоге помощник исправника кратко подытоживал, что жалоба Платонова «не заслуживает уважения, и наложенная на них недоимка должна подлежать ко взысканию» ${ }^{31}$.

21 мая в губернское управление поступил ответ от чиновника по крестьянским делам 1-го участка Бийского округа ${ }^{32}$. Чиновник также целиком был на стороне казаков и утверждал, что «никаких притеснений доверителям Платонова старожилами казаками делаемо не было», а напротив, казаки «сами испытывали от них притеснения благодаря численному превосходству их». Чиновник с неодобрением писал о «привилегированном» положении, которое создали себе переселенцы: «прожив в поселке Терском с лишком 20 лет, не зная над собою никакой власти и не относя никаких повинностей, ни денежных, ни натуральных, переселенцы естественно остались крайне недовольны изданным предшественником Вашего Превосходительства распоряжением (30 января 1890 г. № 168)»33. Таким образом, чиновник игнорирует факт неоднократных жалоб переселенцев на давление старожилов, игнорирует само наличие разных групп переселенцев и рисует исключительно одностороннюю картину. Как обычно в такого рода конфликтах, низовые чиновники имели вполне определённое мнение. Иногда они пытались его маскировать, демонстрируя стремление к объективности; но Антоньевский случай - не из этого ряда.

На основании полученных ответов губернское управление принялось сочинять собственный ответ в царскую канцелярию ${ }^{34}$. Дело оказалось долгим. Судя по исправлениям в датировке на черновом отпуске этого документа, работа над ним началась в июне, а

${ }^{31}$ ГАТО. Ф. Ф-3. Оп. 44. Д. 148. Л. 7 об.

32 Там же. Л. 18-19 об.

${ }^{33}$ Там же. Л. 18-18 об.

34 Там же. Л. 48-50. 
завершилась 12 августа. Не вдаваясь в тонкости, автор ответа утверждал, что жалобщики «поселились в поселке Терском более 20 лет назад с условием уплаты подлежащих сборов за пользование землями». После того, как все полутона были, таким образом, обрезаны, оставалось только пересказать суть законов 1868 и 1870 гг., указать на то, что льготный к переселенцам закон 13 июля 1889 г. относится к казённым землям (а не к Алтайскому округу) и сделать вывод о том, что прошение «не заслуживает удовлетворения». Что и было сделано. Чтобы более наглядно представить тенденциозность документа, можно указать на одно внутреннее противоречие: утверждение о давнем (20 лет назад) поселении жалобщиков в Терском соседствует со словами о том, что повод к жалобе дало постановление М. А. Таубе 1889 г., касавшееся только новых переселенцев (не учтённых постановлением Н. Г. Казнакова 1875 г.). Первое утверждение было нужно автору документа, чтобы очернить переселенцев (20 лет не плативших должных сборов), последнее - чтобы обелить казачьего радетеля (который, вроде бы, не пытался изменять правила задним числом). Нестыковки между этими двумя положениями автор, видимо, не заметил. Предвзятость его очевидна.

Императорская квартира составила свой ответ Платонову с опорой на губернаторские данные, и это был отказной ответ. Документ этот прост и не заслуживал бы упоминания, если бы не входящий штамп Томской губернской тюремной инспекции, дата которого (5 октября 1892 г.) на три дня отстаёт от даты получения в крестьянском присутствии Томского губернского управления (2 октября). Штамп крестьянского присутствия встречается на других документах дела многократно (и это логично); тюремной инспекции - ни разу (что тоже логично). Почему для исполнения этот документ направили не исправнику, а в тюремное ведомство? Эта загадка остаётся пока нерешённой. На2017. T. 18, № 2. C. 359-383 
прашивается предположение, что Артамон Платонов за свою борьбу против казаков успел попасть в тюрьму (хотя и странно, что этот факт не отложился в других документах).

Не вполне понятен и последний документ из дела - расписка Платонова от 26 января 1893 г. Кажется логичным, что это та самая подписка, требованием которой завершается отношение из императорской канцелярии - подписка в ознакомлении с отказом на прошение государю императору. Однако такая подписка должна была уйти в столицу в подлиннике, в томском деле могла остаться лишь копия. Но подписка ${ }^{35}-$ подлинная: здесь и личная подпись атамана Мархинина, и буквы, выведенные отставным унтер-офицером Григорием Лудцевым (за неграмотного Платонова и за неграмотного же полицейского сотского). Притом в самой расписке об императорской канцелярии не упоминается: «предписание Томскаго Губернатора от 30 декабря 1892 года за № 3661, Г. Бийскому Окружному Исправнику, мне объявлено и приговор данный мне обществом на ходатайство от 25 августа 1891 года, я получил в чем и подписуюсь» ${ }^{36}$. Если бы речь шла о предписании объявить постановление императорской канцелярии, то всё-таки была бы странной разница в датах: губернаторское предписание исправнику было отправлено почти через 3 месяца после получения решения из императорской квартиры. Ясно, значит, что губернаторское предписание от 30 декабря 1892 г. не связано с прошением в адрес царя. А с чем связано, и о каком общественном приговоре речь?

На этот вопрос можно предположить простой ответ: «для полноты коллекции» после получения самого главного ответа от «хозяина земли русской» крестьянину всё же вручили и отказы по его обращениям к губернатору - с возвращением приговора от 6 августа

${ }^{35}$ ГАТО. Ф. Ф-3. Оп. 44. Д. 148. Л. 56.

36 Там же. 
1891 г., которым терские переселенцы подтверждали полномочия своего доверенного. Однако та доверенность сохранилась в деле в подлиннике, достоверность которого несомненно свидетельствуется разнобоем почерков среди подписей.

Все эти особенности последних двух документов заставляют думать, что заключительный этап кризиса был более напряжённым, чем можно предположить по незначительным архивным отзвукам. Вероятно, за кадром остались бурные события, связанные с заключением Платонова в тюрьму. И не исключено, что власть в лице Г. А. Тобизена всё-таки заставила казаков пойти на какие-то уступки, позволившие переселенцам по-настоящему устроиться на бывших казачьих землях.

Если подытоживать Антоньевский случай как историю борьбы вокруг ресурсов общего пользования, то можно сделать одно существенное дополнение к набору классических случаев Э. Остром. Если отвлечься от государства и других внешних источников влияния, то в классических случаях борются две силы: общество, стремящееся к сохранению общего ресурса «навсегда», и нарушители, живущие одним днём. На землях Юго-Западной Сибири в последней четверти XIX века боролись два, а при ближайшем рассмотрении - даже три общества (казаки-старожилы, «приёмные переселенцы» и «новые переселенцы»), каждое из которых было заинтересовано в «вечном» существовании общего ресурса в виде сельскохозяйственных земель (пашни, покосы, выгоны). Однако разница в исходном уровне жизни (привычка к малоземелью у одних, к земельному избытку - у других) привела к тому, что они по-разному определяли рубеж неприемлемости в вопросе о плотности заселения общей территории.

При всём том каждая из трёх групп, выступающих в Антоньевском конфликте, проявила высокую склонность к самоорганизации и к поиску взаимоприемле2017. T. 18, № 2. C. 359-383 
мых соглашений с оппонентами. И хотя роль государственной власти (в лице её местных представителей) оказалась существенной, всё-таки именно на сельское общество (будь то казачье или крестьянское) ложилась задача практического решения жизненно важных спорных вопросов, возникавших по ходу заселения Сибири.

\section{Өписок использованной литературы}

1. Вятка и Вятчане в воспоминаниях ученого-агронома Вячеслава Юферева [Электронный ресурс] / публ. В. Д. Сергеева // Герценка : Вятские записки: [Науч.-попул. альм.] : Вып. 3 / редкол.: Н. П. Гурьянова (сост.) и др. - Киров : Киров. ОУНБ им. А. И. Герцена, 2002. - Режим доступа : http:// www.herzenlib.ru/almanac/number/detail.php?NUMBER=nu mber3\&ELEMENT=gerzenka3_5_1(29.12.2016).

2. Мырзахметова А. Ж. Переселение в системе государственной политики в Российской империи в конце XIX - начале XX веков: социально-экономический и правовой аспекты [Электронный ресурс] / А. Ж. Мырзахметова / / Вестник КарГУ. - 2008. - Режим доступа : http:/ / articlekz.com/article/5030 (29.12.2016).

3. Старцев А. В. Соблюдение служебной дисциплины и законности при исполнении служебных обязанностей чинами полиции Томской губернии в конце XIX - начале XX в.: по материалам Бийского округа (уезда) / А. В. Старцев, В. М. Антропов // Алтайский юридический вестник. - 2015. - № 3 (11). - С. 15-20.

4. Успенский Г. И. Поездки к переселенцам [Электронный ресурс] / Г. И. Успенский / / Lib.ru : Библиотека Максима Мошкова. - Режим доступа : http:/ /az.lib.ru/u/uspenskij_g_i/ text_0530.shtml (29.12.2016).

5. Яковенко А. В. Томские губернаторы : биобиблиографический указатель / А. В. Яковенко, В. Д. Гахов. - Томск : Ветер, 2012. - 223 с.

\section{Информация об авторах}

Кирилюв Алексей Константинович - кандидат исторических наук, доцент, кафедра отечественной истории, Новосибирский государственный университет; старший научный сотрудник, сектор истории второй половины XVI - начала 
XX в., Институт истории СО РАН, Россия, 630090, Новосибирск, ул. Николаева, 8, e-mail: alkir.nsk@gmail.com.

Гордеева Мария Александровна - референт директора, Институт истории СО РАН, Россия, 630090, Новосибирск, ул. Николаева, 8, e-mail: sharshova@yandex.ru.

Караваева Анастасия Геннадьевна - директор, Государственный архив Томской области, 634009, г. Томск, ул. Водяная, 78, e-mail: anast@post.tomica.ru.

\section{$4 \nabla$}

Alexey K. Kirillov - Ph.D. in History, Associate Professor, Russian History Department, Novosibirsk State University; Senior Researcher, 2nd Half of 16th - Early 20th Century History Sector, Institute of History of the SB RAS, 8, Nikolaev Str., Novosibirsk, 630090, Russian Federation, e-mail: alkir.nsk@gmail.com.

Mariya A. Gordeeva - Director's Secretary, Institute of History of the SB RAS, 8, Nikolaev Str., Novosibirsk, 630090, Russian Federation, e-mail: sharshova@yandex.ru.

Anastasiya G. Karavayeva - Director, State Archive of Tomsk Region, 78, Vodjanaja, Tomsk, 634009, Russian Federation, e-mail: anast@post.tomica.ru.

\section{Для цитирования}

Кириллов А. К. Сельскохозяйственные ресурсы общего пользования в западносибирской деревне: механизм возникновения старожильческо-переселенческих конфликтов в 1870 1890-е годы. Антоньевский случай / А. К. Кириллов, М. А. Гордеева, А. Г. Караваева // Историко-экономические исследования. - 2017. - Т. 18, № 2. - C. 359-383. - DOI: 10.17150/23082588.2017.18(2).359-383.

\section{$47: 4$ :}

Kirillov A. K., Gordeeva M. A., Karavayeva A. G. Agricultural Common-Pool Resources in the West Siberia Village: Starting Mechanism of Conflicts between Peasant Migrants and Old Dwellers in the 1870s-1890s. The Case of Antonievskaya. Istoriko-ekonomicheskie issledovaniya = Journal of Economic History \& History of Economics, 2017, vol. 18, no. 2, pp. 359-383. DOI: 10.17150/2308-2588.2017.18(2).359-383. (In Russian). 